\title{
Development of Circuit Games to Develop Rugged Motoric Ability and Language
}

\author{
Siti Dyah Purwatiningsih ${ }^{1, a}$, Bachtiar S. Bachri ${ }^{1, b}$, Rachma Hasibuan ${ }^{1, c}$ \\ ${ }_{1}$ Postgraduate of Basic Education, Surabaya State University, Surabaya, Indonesia \\ E-mail: a dyah.purwati99@gmail.com; b bachtiarbachri@unesa.ac.id; c rachmahasibuan@yahoo.com; \\ ${ }^{*}$ Corresponding Author \\ Whatsapp Number [+62-81232880095]
}

How to Cite : Purwatiningsih, S., Y., Bachri, B., S., Hasibuan, R. (2019). Development of Circuit Games to Develop Rugged Motoric Ability and Language. International Journal for Educational and Vocational Studies, 1 (3), 166-169.

\section{ARTICLE HISTORY}

Received: 2 June 2019

Revised: 18 June 2019

Accepted: 2 July 2019

\section{KEYWORDS}

Circuit game,

Gross motor,

Language

\section{ABSTRACT}

The purpose of this study is to analyze the feasibility and effectiveness of the circuit game of the recognize me have in developing gross motor skills and children's language in group A at RA Al-Qodir Wage Sidoarjo. This development research uses the Dick \& Carey research and development model. The result of the development is circuit game products to develop gross motor skills and children's language in group $A$. The development of the media includes material about the introduction of Indonesian culture, namely traditional clothes in Indonesia. The study was conducted in class A1 at RA Al-Qodir Wage Sidoarjo. Based on the formative test to experts and children obtained qualitative and quantitative data, qualitative data are suggestions from experts and quantitative data in the form of a percentage of child observation sheets. From the percentage of assessment of formative tests experts and also children, the circuit game is feasible and effective to be used in learning to develop gross motor skills and children's language in group A in RAAI-Qodir Wage Sidoarjo.

This is an open access article under the CC-BY-SA license.

\section{INTRODUCTION}

Children aged 4-6 years are part of early childhood. Early childhood education is an education that provides the most important basis for children's education in the future. Early childhood education is a sensitive period for children or an effective period to develop various aspects of child development, including the development of physical-motor skills, cognitive,language, social-emotional, arts, moral, and religious values. Early childhood, efforts to develop the full potential of children must be implemented so that the child's growth and development are optimally achieved.

According to the NAEYC (in Aisyah 2008) revealed that early childhood is children in the age range of $0-8$ years, which are covered by educational programs in child care parks, family daycare for children (family child care home), good early childhood education private or public. Meanwhile, according to Mustafa (in Susanto 2017), early childhood is children in the age range between 1-5 years. This understanding is based on limitations in the field of developmental psychology, which include infants or infants aged 0-1 years, early childhood 1-5 years, late childhood 6-12 years. Furthermore, Bredekamp (in Susanto 2017) divided the group of early childhood into three groups, namely children from infants up to 2 years, children aged 3-5 years, and children aged $6-8$ years. The division of children by age can influence the rules in implementing curriculum in education and child care.

Early childhood has different characteristics in each individual, but in general Hasibuan (2017) argues that early childhood has characteristics namely; (a) each child is unique; (b) children learn through play and trying; (c) the child's attention span is short; (d) children see and understand the world from a different perspective from adults; (e) children are egocentric; (f) children need love and acceptance and exploration, activity and expression.

Children can think creatively through objects that are around them. Children at an early age are the most effective learning periods, children learn through playing both with peers and with objects that are around it. Children tend to be egocentric but still part of social beings who need other friends to play. Children aged 0-8 years still have a short span of concentration power so that in teaching children can not be too long, because children will quickly get bored. Children recognize things by organizing and classifying them into concepts. Children still think symbolically, cannot think abstract 
and complex.

Important aspects to be developed in the process of growth and development of children, one of which is the gross motor aspects. Children who are disrupted by the process of growth and physical development will also be very likely to be disturbed by other aspects, and it may be disturbed in terms of cognitive, language, social-emotional, and also religious and moral values.

Gross motor development in early childhood is different from one child to another. There are children who experience motor development very well, and there are also children who experience obstacles and delays. The difference in growth and physical development of motor children is influenced by gender, pre-natal background, Christmas, until post-natal. According to the Ministry of National Education (2012), the growth and physical development of a child's motor is strongly influenced by the nutritional intake received by the child, children's health, and motor treatment according to the child's development. In line with this opinion, according to Aye et al. (2018), children's motor development is influenced by many things, one of which is gender.

In addition to gross motor development, aspects that need to be developed are aspects of language. Santrock (2014) states that a language is a form of communication, whether it is oral, written, or sign, based on a system of symbols. Language consists of words used by the public, along with rules to arrange various variations and combine words. According to Suhartono (2005), children's language is the language used by children to express desires, thoughts, hopes, requests, and others for the child's personal interests.

Developing the gross motor and language aspects of children can be packaged through play activities that make children happy. One game that can be used to develop gross motor skills and children's language is a circuit game. According to Soekarman (1987), a circuit game is an exercise program that is combined from several training items whose purpose in doing an exercise will not be boring and more efficient. Designing circuit games for young children, between each circuit, must be different from other circuits, it is not permissible for one circuit and another to have the same activity. The purpose of the circuit game is time efficiency, so there should not be the same activity between one circuit with another circuit; it was also revealed by Vega (2013).

The circuit game activity that will be developed in this study is titled "Development of the" Kenali Aku Me "Circuit Game To Develop Course Motor Skills and Storytelling of Children of Group A at RA Al-Qodir Wage." The development of this game is not only used to develop aspects of child development such as motor scales, language, cognitive, social-emotional, and religious and moral values, but games that introduce children to Indonesian culture, one of them is traditional clothes and traditional musical instruments. Getting to know the culture of Indonesia will make children love the Indonesian nation more.

The "Kenali Aku" circuit game is designed to meet the development needs of early childhood, especially in group A children aged 4-5 years. The "Kenali Aku" circuit game is designed as attractive and varied as possible, using easy-to-obtain materials, providing an interesting diversity of colors, and a variety of varied activities. It aims to attract the attention and interest of children in active play activities.

\section{METHODS}

This study uses the Dick \& Carey research and development model. Which include analyzing needs and goals, learning analysis, analysis of students (students) and context, formulating performance goals or performance, developing instruments or test kits, developing learning strategies, designing and conducting formative evaluations, and making revisions. The results of the development in the form of circuit game products to develop gross motor skills and language of children in group A. The development of the media includes material about the introduction of Indonesian culture, namely traditional clothes in Indonesia. The study was conducted in class A1 at RA Al-Qodir Wage Sidoarjo.

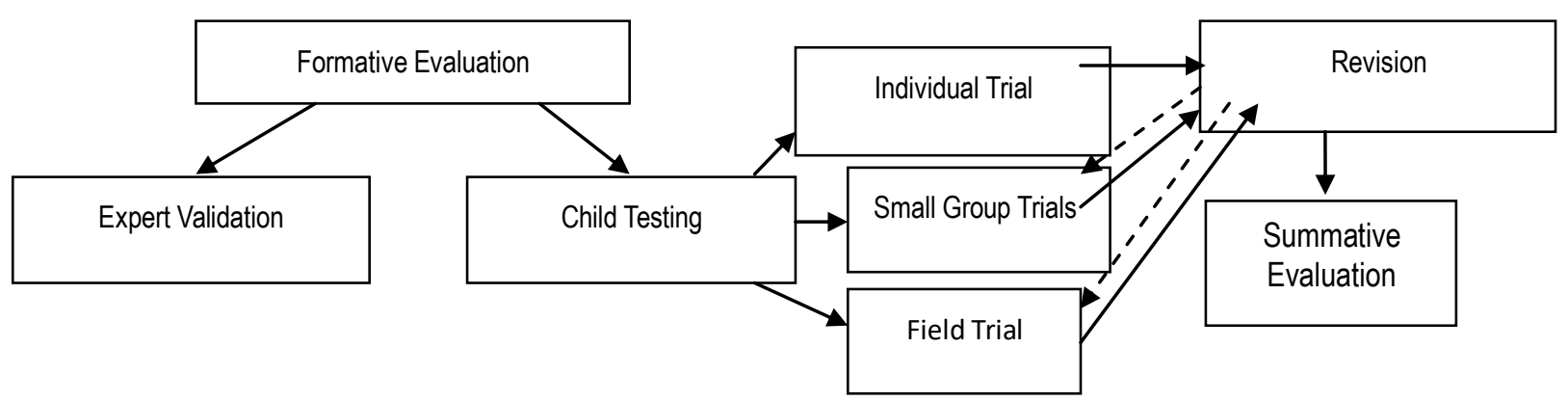

Figure 1. Trial Design

The research subjects in this study were children of Group A1 in RA Al-Qodir Wage, amounting to 30 children. With his class teacher as a teacher and researcher as an Observer. Validation test with experts is done by requesting validation to 2 experts, namely experts in language development and gross motor skills of early childhood, and media experts. The type of data obtained from the trial product development activities of the "Kenali Aku" circuit game is quantitative data and qualitative data. Quantitative data were obtained from assessment scores at the field trial stage, while qualitative data were obtained from the results of expert 
validation, individual trials, and small group trials in the form of responses and suggestions for improvement. The instruments used in this research development are interviews, observation sheets, and questionnaires. Interviews are used to determine the problems that occur during initial observation and determining changes in the assessment of the game model given to children by using conversational techniques to children. The interview instrument was used at the field trial stage before and after the activity.

Data analysis techniques about the development of the game circuit "Kenali Aku" is done by considering input, comments, and suggestions from experts using the Guttman scale that is revised and not revised. Analysis of the data to determine the effectiveness of the "Kenali $\mathrm{Aku}^{\prime}$ circuit game by using a comparison of gross motor skills before treatment or before the game activities are carried out after treatment or after the activities are carried out. The trial design used is the type of One Group Pretest Posttest Design.

\section{RESULTS AND DISCUSSION}

The results of the validation by two experts indicate that the game circuit is suitable for use in the next step, which is the individual trial phase. In the individual trials, the results obtained all children get maximum results that are $100 \%$. The results of individual trials show the percentage of acquisition of children more than $51 \%$, so it can be concluded that the individual trials are feasible to be continued in the next trial that is a small group trial.

A small group trial was conducted on 10 Group A children in RA Al-Qodir Wage. The results of small group trials conducted by ten children showed maximum results of $100 \%$. Scoring on each indicator obtained indicator 1 $100 \%$, indicator $2100 \%$, indicator $3100 \%$, indicator 4 $100 \%$, indicator $5100 \%$, indicator $6100 \%$, indicator 7 $100 \%$. Each indicator in the small group trial has obtained maximum results that are $100 \%$, so it can be concluded that each indicator has obtained a percentage of eligibility. The percentage results obtained from 10 children and seven indicators have reached a maximum result of $100 \%$ so that it can be concluded that the circuit game "Kenali Aku" is eligible for use in the next trial that is a large group or field trial.

The effectiveness of enhancing gross motor and language development through the "Kenali Aku" circuit game is done by initial measurement (Pretest) and final measurement (Posttest). The ability of children before and after activities with the "Kenali Aku" circuit game can be known through large group or field trials.

The effectiveness of the "Kenali Aku" circuit game that has been developed and used in group A children, is calculated using SPSS 20 software, the results of calculations using the SPSS are as Table 1 and 2 .
Table 1. Wilcoxon Signed Ranks Test

Ranks

\begin{tabular}{|c|c|c|c|c|}
\hline & & $\mathrm{N}$ & Mean Rank & Sum of Ranks \\
\hline & Negative Ranks & $0^{\mathrm{a}}$ & .00 & .00 \\
\hline POSTTEST & - Positive Ranks & $30^{\mathrm{b}}$ & 15.50 & 465.00 \\
\hline \multirow[t]{2}{*}{ PRETEST } & Ties & $0^{c}$ & & \\
\hline & Total & 30 & & \\
\hline
\end{tabular}

a. POSTTEST $<$ PRETEST
b. POSTTEST $>$ PRETEST
c. POSTTEST $=$ PRETEST

Table 2. Statistic Test

Test Statistics ${ }^{a}$

\begin{tabular}{lr}
\hline \multicolumn{2}{c}{ POSTTEST - PRETEST } \\
\hline$Z$ & $-4.804^{\mathrm{b}}$ \\
\hline Asymp. Sig. (2-tailed) & .000 \\
\hline \multicolumn{2}{c}{ a. Wilcoxon Signed Ranks Test } \\
b. Based on negative ranks.
\end{tabular}

The conclusion from the explanation above is that the results of the hypothesis test used are the "test statistics" output table showing Asymp. Sig. (2-tailed) is worth 0,000. Because the value of $0,000<0.05$, it can be concluded that $\mathrm{H}-\mathrm{a}$ is accepted, meaning that there is a difference in scores between before and after being given the "Kenali $\mathrm{Aku}^{\prime}$ circuit game. The data shows that the circuit game is effective to be used as a game that can improve the gross motor skills and language of group A children in RA Al-Qodir Wage-Sidoarjo.

\section{CONCLUSION}

Based on the results of this development research, it can be concluded that the circuit game "Kenali Aku" is feasible to be used in improving gross motor and language development in group A children in kindergartens. The "Kenali Aku" circuit game is also effectively used in developing gross motor skills and the language of children in group $\mathrm{A}$. This is proven through the hypothesis test used, the "test statistics" output table shows Asymp. Sig. (2-tailed) is worth 0,000 . Because the value of $0,000<0.05$, it can be concluded that $\mathrm{H}-\mathrm{a}$ is accepted, meaning that there is a difference in scores between before and after being given the "Kenali Aku" circuit game.

\section{REFERENCES}

Aisyah, dkk. (2008). Perkembangan dan Konsep Dasar Pengembangan Anak Usia Dini. Jakarta: Universitas Terbuka

Hasibuan. (2017). Perencanaan Pembelajaran PAUD. Surabaya: UNESA University Press

Susanto. (2017). Pendidikan Anak Usia Dini: Konsep dan Teori. Jakarta: Bumi Aksara 
Aye, Dkk. (2018). Gross Motor Skill Development of Kindergarten Children in Japan. Journal of the Society Physical Therapy Science: IPEC Inc

Depdiknas. (2012). Panduan Mengajar di TK/RA. Jakarta: Balitung Departemen Pendidikan Nasional

Santrock. (2014). Psikologi Pendidikan (Educational Phsychology) edisi 5. Jakarta: Salemba Humanika

Soekarman. (1987). Dasar Olahraga Untuk Pembina Dan Atlet. Jakarta: Inti Idayu Press Depdiknas

Suhartono. (2005). Perkembangan Ketrampilan Bicara Anak Usia Dini. Jakarta: Depdiknas. 